\title{
Miocene Foraminifera Biostratigraphy and Interpretation North Deep Sea Block of the Congolese Atlantic Basin
}

\author{
Nehl Dorland Kobawila ${ }^{*}$, Hilaire Elenga ${ }^{1,2}$, Louis Richard Ngatse ${ }^{3}$ \\ ${ }^{1}$ Department of Geology, Faculty of Science and Technology, Marien Ngouabi University, Brazzaville, Republic of Congo \\ ${ }^{2}$ Geological and Mining Research Center, Brazzaville, Republic of Congo \\ ${ }^{3}$ National Petroleum Society of the Congo, Brazzaville, Republic of Congo \\ Email: *kobawila_nehldo@hotmail.fr
}

How to cite this paper: Kobawila, N.D., Elenga, H. and Ngatse, L.R. (2021) Miocene Foraminifera Biostratigraphy and Interpretation North Deep Sea Block of the Congolese Atlantic Basin. Open Journal of Geology, 11, 253-274.

https://doi.org/10.4236/ojg.2021.117015

Received: May 17, 2021

Accepted: June 20, 2021

Published: July 26, 2021

Copyright $\odot 2021$ by author(s) and Scientific Research Publishing Inc. This work is licensed under the Creative Commons Attribution International License (CC BY 4.0).

http://creativecommons.org/licenses/by/4.0/

\begin{abstract}
This work is the subject of the biostratigraphic and palaeoenvironmental study of the North Deep Sea area of the Congolese Miocene Atlantic Basin. This study is made from samples of lateral cores, drill cuttings and electrical logs. Lithology generally exhibits an irregular alternation of weakly indurated grey clay, light grey siltstones, and whitish, quartzitic sand, medium to coarsegrained, sub-angular to rounded. The presence of glaucony indicates that sediments have been deposited in a calm and reducing environment. The entire formation is fossiliferous. Micropaleontological analysis revealed 120 species of foraminifera including 98 planktonic (81.67\%) and 22 benthic (18.33\%) species used for biozonation, dating and interpretation of palaeoenvironments. Similarly, the bio-events of plankton foraminiferal, characterized by the level of the first appearance of certain species, have made it possible to identify fifteen biozones (Globorotalia plesiotumida, Globorotalia merotumida, Globorotalia acostaensis, Globorotalia menardii, Globigerina nepenthes, Globorotalia siakensis, Globorotalia fohsi, Globorotalia praefohsi, Globorotalia peripheroacuta, Globorotalia peripheroronda, Praeorbulina sicana, Catapsydrax dissimilis, Globigerinatella insueta, Paragloborotalia kugleri and Globorotalia kugleri) corresponding to age between Aquitanian and Lower Pliocene. Biofacies analysis of foraminifera has identified palaeoenvironments that vary from open marine environments, bathyal to abyssal.
\end{abstract}

\section{Keywords}

Biostratigraphy, Foraminifera, Palaeoenvironments, Miocene,

Congolese Atlantic Basin 


\section{Introduction}

The history of the Congolese coastal sedimentary basin is linked to the Cretaceous opening of the South Atlantic between Africa and South America. The work of Desthieux et al. [1] presents a geodynamic evolution divided into three phases: antesaliferous, saliferous and post-saliferous. This basin, whose economic interest is linked to oil exploitation, has been the subject of numerous studies in the various fields of geology (tectonics, structural geology, stratigraphy, sedimentology, and micropaleontology) which provided interesting details on the lithological succession and the age of the facies. The biostratigraphic and micropaleontological studies, Kouyoumontzakis; M'Boro; N'Gatse; Massala; Giresse et al.; Giresse \& Baloka; Mbani [2]-[9] carried out are mostly of Cretaceous age. Available data on Tertiary biostratigraphy, including Miocene biostratigraphy, are rare and fragmentary. Thus, few biostratigraphic studies have been carried out and published on the Miocene of the Congolese coastal basin. A large part of the existing studies on Miocene result from the correlation of the work carried out in the sub-region (Angola, Gabon and Cameroon). Although the Miocene was established during the oceanization, it is currently an interesting prospect in the oil exploration of the Congolese offshore. From the Oligocene to the Miocene, sedimentological data have prompted the search for ancient fluvial channels. These paleo-channels contain sands that have proven to be high-quality traps for migrating hydrocarbons. With a view to further exploration, a biostratigraphic study was carried out on four boreholes in the North Deep Sea block of the Congolese Atlantic Basin. This study area is located offshore in the Congolese Atlantic baisn with water depths varying from $500 \mathrm{~m}$ to $3000 \mathrm{~m}$. The area is characterized by a thinning of the antesaliferous series and by the presence of chenalising structures (Figure 1). The objectives of this study are:

- To carry out a chronostratigraphic calibration from the biozones;

- To characterize the deposit environments based on lithological analysis and on the determination of biozones. This study presents the invotory of biozones, the chronostratigraphic calibration of remarkable biostratigraphic events at the scale of the interval studied, and the palaeoenvironmental interpretation of sedimentary deposits.

\section{Material and Methods}

Study material includes 92 samples of side cores, 120 drill cuttings and 5 electrical logs (Gamma Ray) from four wells called BM01, NM01, RM01 and SGM01, whose total depth varies between $1670 \mathrm{~m}$ and $3400 \mathrm{~m}$.

The methodology consists in collecting the samples of loose sediment every 10 or $20 \mathrm{~m}$ for the foraminifera, and every $10 \mathrm{~m}$ for the nannofossils. Quantitatively, 30 grams of each sample are subjected to defloculation and sieving operations. Samples are carefully washed through a $63 \mu$ sieve. The dried residue passes through a sieve set of $500 \mu, 500-250 \mu, 250-125 \mu$ and less than $125 \mu$. Taxonomic analysis 


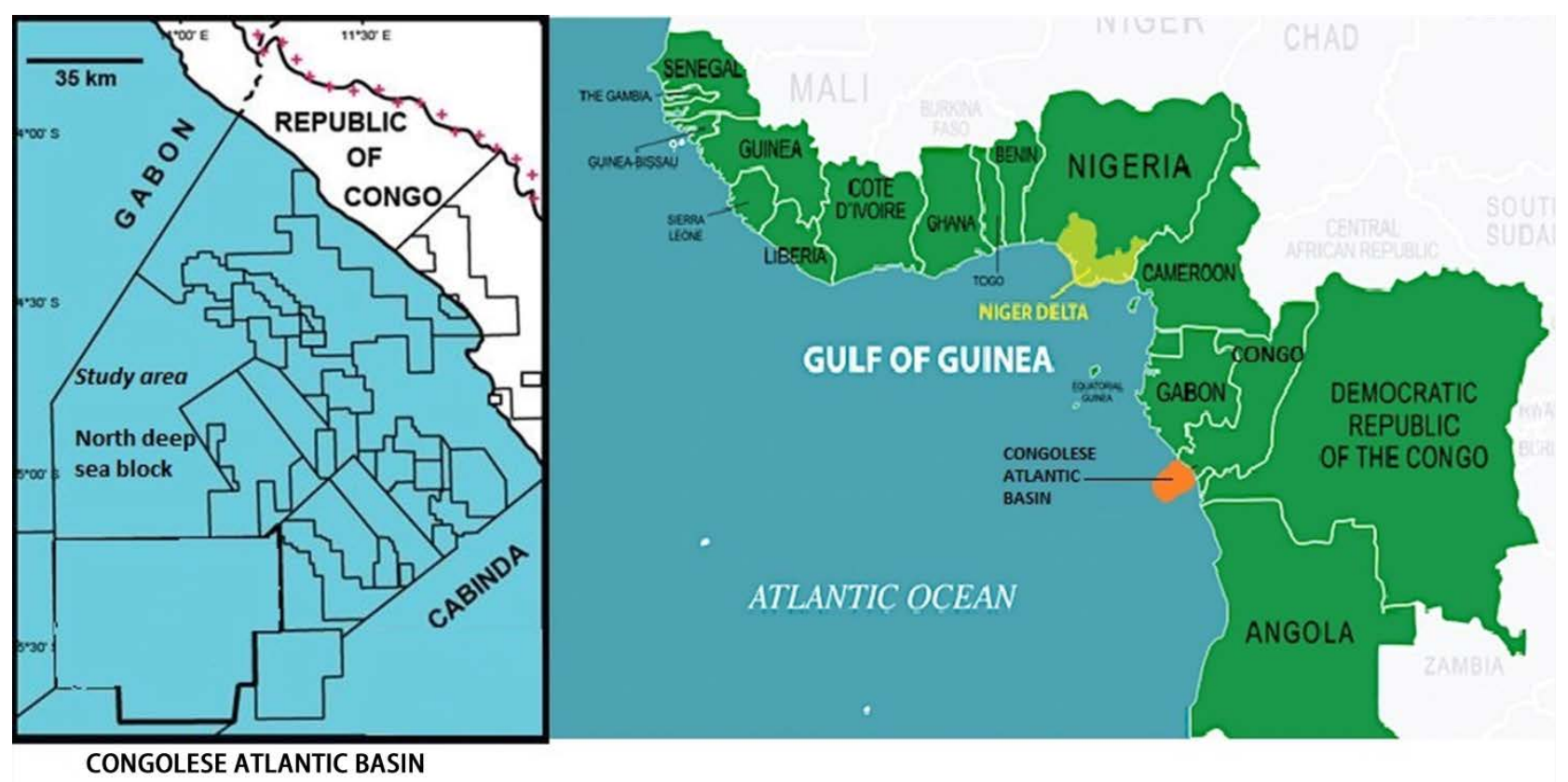

Figure 1. Location of the study area.

and identification of planktonic foraminifers are based on the documents and illustrations depicted in the work of Blow [10] [11] with modifications by Bolli \& Saunders [12], Loeblich and Tappan [13], followed by recent amendments by Hardenbol et al. [14], Berggren et al. [15] and Olsson et al. [16], and in comparison to the work of Mboro et al. [17]. The micropaleontological preparations of the lateral cores were selected to study their total micropaleontological contents, and the samples of the drill cuttings were prepared for quantitative micropaleontological and nannofossil analysis. At the end of the biostratigraphic analyses, the results were integrated into the diagraph and lithofacie data in order to allow a strategic interpretation of the diagraphs, on which the stratigraphic and paleo-environmental cutting off the North Deep Sea block is based.

\section{Results}

\section{1) LITHOSTRATIGRAPHY}

The lithological description of the core samples and cuttings associated with the analysis of the Gamma Ray logs shows that the interval drilled concerns the Paloukou formation (clay-silty, sandy and limestone). The sections studied generally consist of three units in the direction of drilling:

- Unit 1: Upper Miocene (1816 m - 2556 m)

It generally has an alternation of greenish grey to dark grey clay, silty, transparent to opaque sand, very fine to coarse, and light grey siltstone. This unit is very fossiliferous with a good diversity of fossils. Its thickness varies from $250 \mathrm{~m}$ to $740 \mathrm{~m}$ approximately.

- Unit 2: Medium Miocene (2556 m - $2926 \mathrm{~m})$

This section is dominated by an irregular alternation of greenish grey clay, 
weakly indurated, brown grey siltstone, loosely consolidated more or less clayey, and translucent sand with fine to locally coarse, sub-rounded quartz grain. The medium Miocene is moderately fossiliferous and contains abundant glauconite. This interval is between $130 \mathrm{~m}$ and $370 \mathrm{~m}$ thick.

- Unit 3: Lower Miocene (2926 m - 3400 m)

This interval is composed of grey to beige clay, silty to sandy silto-sandy, little to well indurated; followed by grey to whitish siltstone; of whitish-white sand, quartzitic, medium to coarse grained, sub-angular to rounded. This unit is low fossil and has a reduced diversity of fossil species. It is about 450 $\mathrm{m}$ thick.

\section{2) BIOSTRATIGRAPHY}

120 species of foraminifers, including 98 planktonic (81.67\%) and 22 benthic (18.33\%), have been identified and used for dating, biozonation and palaeoenvironmental interpretation. From the different species of foraminifers collected in the North Deep Sea block, the different stratigraphic cuts of the Miocene are defined on the basis of the Blow [10] [11] classification (Table 1).

Upper Miocene Limit-Lower Pliocene

In the Deep North Sea block, the upper Miocene-lower Pliocene boundary is marked by the first appearance of Globorotalia plesiotumida and the last appearance of Globorotalia margaritae located at $1816 \mathrm{~m}$ of depth. The foraminifers Globorotalia juania, Globorotalia conoide and Globorotaloides variabilis are also recorded slightly below this depth.

a) Upper Miocene (1816 m - $2556 \mathrm{~m}$ )

- Messinian (1816 m - $2150 \mathrm{~m}$ )

It is found in three wells. In the direction of drilling, the summit of the Messinian is encountered at 1816 meters of depth by the first appearance of Globorotalia tumida plesiotumida. The base of this interval is marked by the appearance of Globorotalia merotumida at $2150 \mathrm{~m}$ depth. The fossil harvest is abundant and makes it possible to distinguish in the direction of drilling, the presence of planktonic foraminifers Globorotalia tumida, Globorotalia panda, Globorotalia venezuelana, Neogloboquadrina acostaensis, Globigerina angustiumbilicata, Globigerina obesa, Orbulina suturalis, Praeorbulina glomerosa, Globigerinoides conglobatus, Orbulina universa, Neoglobigerina pachyderma, and Neogloboquarina acostaensis, all characteristics of this interval.

Benthic foraminifera Martinotiella communis, Sphaeroidinellopsis disjuncta, Heoglundina elegans, Pullenia bulloides, Cibicidoides pseudoungerianus, Bulimina alazanensis are also collected in this interval. In addition, we also note the subsequent appearance at the descent of the fossils Discoaster quiqueramus at $2060 \mathrm{~m}$ and Discoaster berggrenii at $2100 \mathrm{~m}$ of depth.

- Tortonian (2150 m - $2556 \mathrm{~m}$ )

Micropaleontological harvest is good. In the direction of drilling, the top is marked by Globorotalia merotumida at $2298 \mathrm{~m}$ depth and the base is at $2556 \mathrm{~m}$ depth with the first appearance of Globigerina nepenthes. This area is also characterized by the first appearance of Globorotalia mayeri, Globorotalia acostaensis 


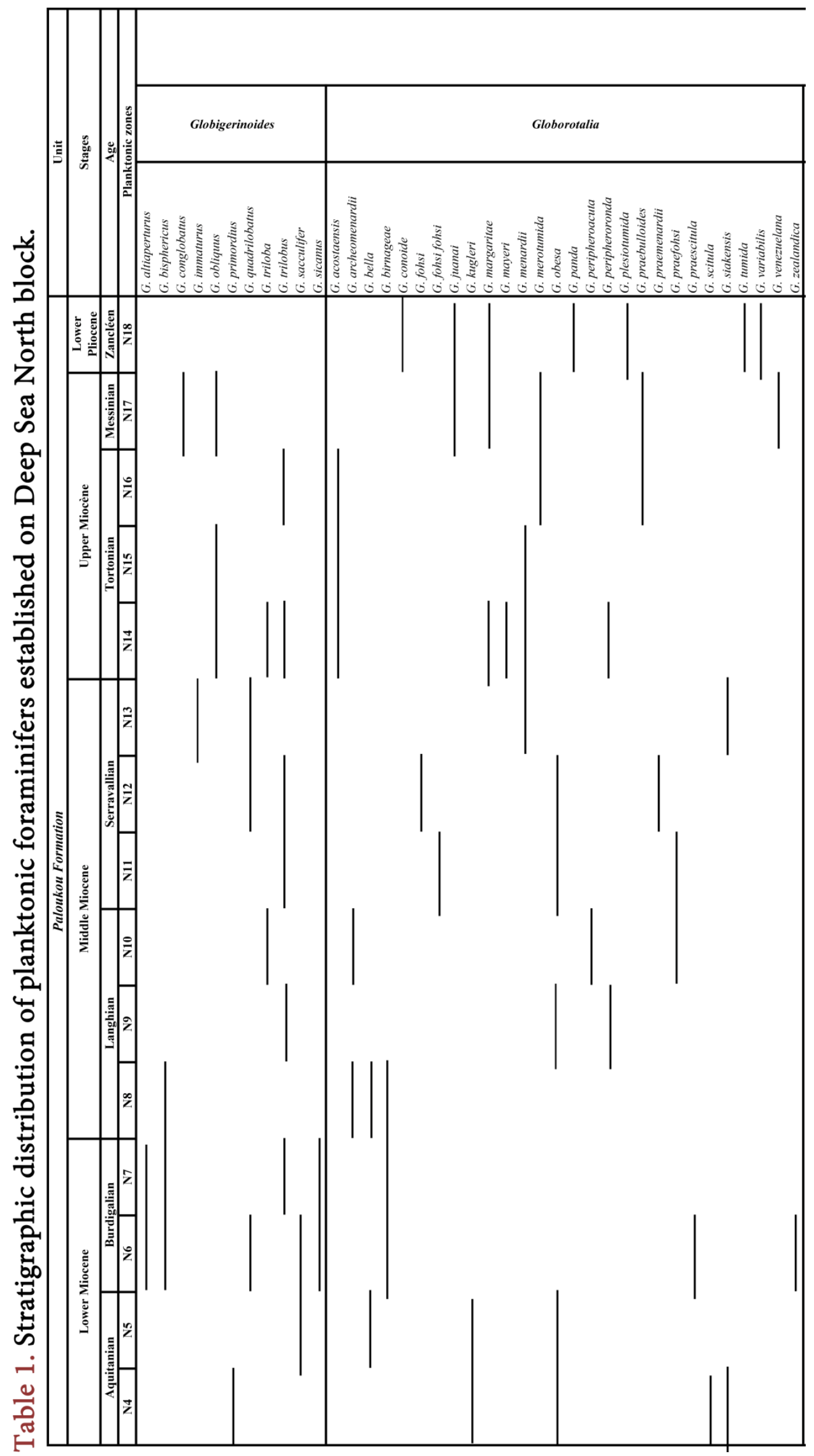




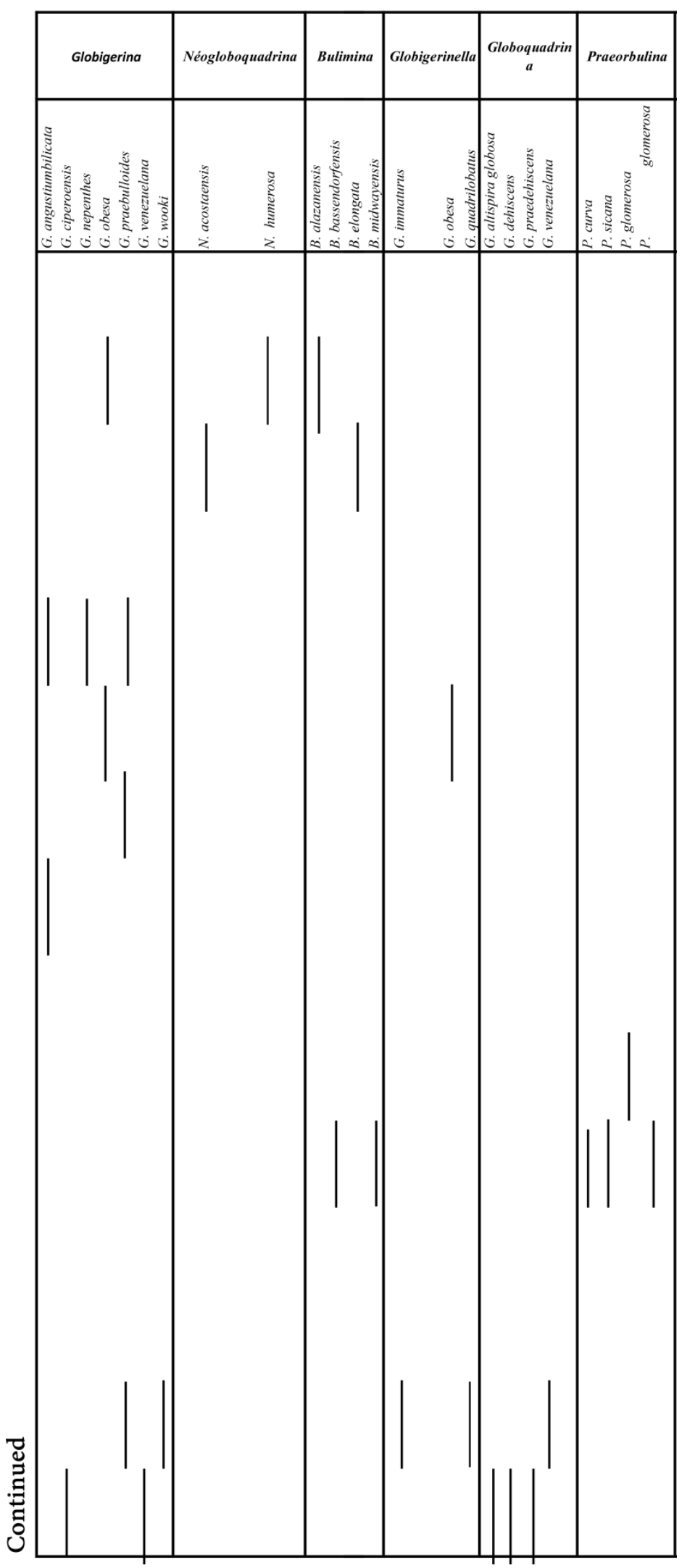




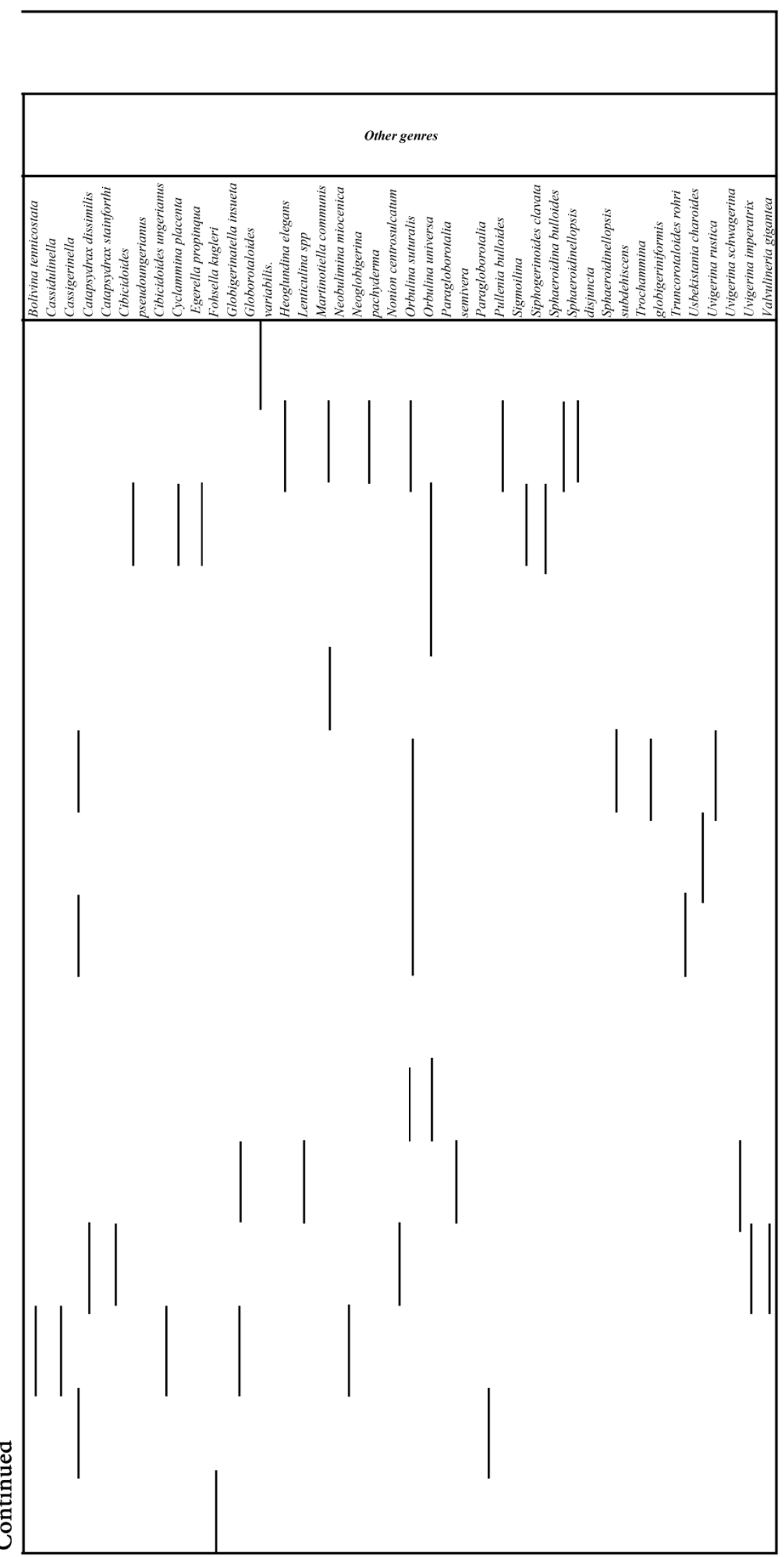


with the disappearance of Neogloboquadrina acostaensis and Neogloboquadrina humerosa. We record the presence of planktonic foraminifera Globorotalia praebulloides, Globigerina praebulloides, Globigerina angustiumbilicata, Globigerinoides trilobus, Globigerinoides triloba, Globigerinoides obliquus, Globigerinoides immaturus, Orbulina universa, as well as the presence of benthic foraminifera such as Bulimina elongata, Cibicidoides pseudoungerianus, Sigmoilina schlumbergeri, Martinottiella communis, Cyclammina placenta, Egerella propinqua, Siphogerinoides clavata and Sphaeroidinellopsis subdehiscens.

b) Middle Miocene (2556 m - $2926 \mathrm{~m}$ )

- Serravalien (2556 m- $2720 \mathrm{~m})$

The summit is marked by the first appearance of Globigerina nepenthes at a depth of $2556 \mathrm{~m}$. The foraminifera Globorotalia praefohsi and Truncorotaloides rohri represent the base of the Serravalien at $2720 \mathrm{~m}$. The micropaleontological harvest in this area is moderate. Some samples are not very fossiliferous, while others contain casts of broken foraminifera. This section records, still in the direction of drilling, by the presence of the assemblages of Globorotalia acostaensis, Globorotalia praemenardii, Globorotalia scitula, Globorotalia fohsi, Globorotalia obesa, Globorotalia menardii, Globorotalia siakensis, Globigerinoides trilobus, Globigerinoides obliquus, Globigerinoides quadrilobatus, Globigerinoides immaturus, Globigerina praebulloides, Globigerina nepenthes, Usbekistania charoides, Uvigerina rustica, Orbulina suturalis, Trochammina globigeriniformis and Sphaeroidinellopsis subdehiscens.

- Langhien (2720 m- $2926 \mathrm{~m})$

The roof and base of this section are characterized respectively at $2720 \mathrm{~m}$ and $2926 \mathrm{~m}$ depth by the first appearance of Globorotalia praefohsi and Praeorbulina sicana. The interval is moderately fossiliferous and increasingly calcareous with an increase in planktonic foraminifers and calcareous nannofossils. The basal part is also defined by an increase in the number of agglutinating and radiolar foraminifera. In the direction of the borehole, we can count the presence of Globorotalia peripheroronda, Globorotalia birnageae, Globorotalia bella, Globorotalia archeomenardii, Globorotalia fohsi fohsi, Globorotalia Obesa, Globorotalia praemenardii, Globorotalia scitula, Globigerinoides trilobus, Globigerinoides triloba, Globigerinoides bisphericus, Globigerinatella insueta, Praeorbulina glomerosa, Praeorbulina curva, Praeorbulina sicana, Praeorbulina glomerosa glomerosa, Paragloborotalia semivera, Orbulina suturalis. The lower part differs from the previous one by the abundance of arenaceous foraminifera and by an assemblage of Bulimina midwayensis, Bulimina bassendorfensis, Buliminella aff. Sp, Lenticulina spp Uvigerina schwagerina.

c) Lower Miocene (2926 m - $3400 \mathrm{~m}$ )

- Burdigalian (2926 m - $3195 \mathrm{~m}$ )

This interval is weakly fossiliferous. It is nevertheless characterized by the abundance of benthic foraminifers and by a small quantity of planktonic foraminifera. The top is marked by the first appearance of Praeorbulina sicana while the 
base is marked by the first appearance of Globigerinatella insueta. In the direction of the borehole, this interval records the presence of the foraminifera Globorotalia birnagae, Globorotalia bella, Globorotalia praescitula, Globorotalia zealandica, Globorotalia obesa, Globorotalia peripheroronda, Globigerinoides triloba, Globigerinoides sacculifer, Globigerinoide sicanus, Globigerinoides altiaperturus, Globigerinoides trilobus, Globigerinoides quadrilobatus, Globigerinoides bisphericus, Globigerina woodi, Globigerina praebulloides, Globigerina angustiumbilicata, Globoquadrina venezuelana, Catapsydrax dissimilis, Catapsydrax stainforthi, Sphaeroidina bulloides, Valvulineria gigantea. The Burdigalien is also characterized by the presence of Bolivina tennicostata, Nonion centrosulcatum, Cassidulinella pliocenica, Cibicidoides ungerianus, Neobulimina miocenica, Cassigerinella chipolensis and Uvigerina imperatrix.

- Aquitanian (3195 m - $3400 \mathrm{~m})$ :

The first appearance of the foraminifera Globigerinatella insueta and Globigerinoides primordius respectively characterize the roof and the base of this interval at heights $3195 \mathrm{~m}$ and $3400 \mathrm{~m}$. In addition, this zone includes the presence of the foraminifera Globorotalia obesa, Globorotalia bella, Globigerina praebulloides, Globigerina wooki, Globigerinoides sacculifer, Globigerinoides primordius, Globigerinella obesa, Globigerinella immaturus, Globigerinella quadrilobatus, Globoquadrina venezuelana, Globoquadrina dehiscens, Cassigerinella chipolensis, Paragloborotalia kugleri, Uvigerina rustica and Trochammina globigeriniformis.

\section{Interpretation}

\section{1) BIOZONATION}

The biozonation of Cenozoic planktonic foraminifera has been the subject of several reviews including: Berggren [18] [19] [20] [21]; Blow [10]; Bolli [22]; Bolli and Bermudez [23] [24]; Premoli-Silva and Bolli [25]; Lamb and Beard [26]; Stainforth et al. [27].

The biozones used here are those of Bolli [22] and Blow [10]. The chronostratigraphic framework is taken from Berggren et al. [15]. Across the Congolese Atlantic basin, the observation of certain planktonic and benthic bioevents led to the establishment of 15 biozones (Table 2). These biozones were recognized on the basis of the levels of the first appearance of foraminifera which mark their lower limit. This method, which defines the level of first appearance and the level of extinction of marker species, avoids the contamination problem resulting from collapse which is very common with drill cuttings. However, the level of the first appearance of the supra-adjacent species marks the top of each zone.

It is thus proposed, after international calibration, the following biozonation:

a) Upper Miocene-lower Pliocene limit

- Globorotalia plesiotumida (N18) zone

The presence of the planktonic foraminifera Globorotalia conoides and 
Table 2. Correlation of established biozones.

\begin{tabular}{|c|c|c|c|c|c|}
\hline AGE & $\begin{array}{c}\text { BOLLI, } \\
1966\end{array}$ & $\begin{array}{l}\text { BLOW, } \\
1969\end{array}$ & $\begin{array}{l}\text { Proposed } \\
\text { In this study }\end{array}$ & ZONE & $\begin{array}{l}\text { DEPTH } \\
(\mathrm{m})\end{array}$ \\
\hline $\begin{array}{l}\text { LOWER } \\
\text { PLIOCENE }\end{array}$ & Globorotalia margaritae & $\begin{array}{c}\text { Globorotalia tumida tumida - } \\
\text { Spaeroidinellopsis subdehiscens } \\
\text { paenedehiscence }\end{array}$ & Globorotalia margaritae & N18 & 1816 \\
\hline MESSINIAN & Globorotalia humerosa & Globorotalia tumida plesiotumida & Globorotalia merotumida & N17 & 2150 \\
\hline \multirow{3}{*}{ TORTONIAN } & Globorotalia acostaensis & $\begin{array}{c}\text { Globorotalia acostaensis - } \\
\text { Globorotalia } \\
\text { merotumida }\end{array}$ & Globorotalia acostaensis & N16 & 2265 \\
\hline & Globorotalia menardii & Globorotalia continuosa & Globorotalia menardii & N15 & 2307 \\
\hline & Globorotalia mayeri & $\begin{array}{l}\text { Globigerina nepenthes - } \\
\text { Globorotalia siakensis }\end{array}$ & Globigerina nepenthes & N14 & 2556 \\
\hline \multirow{3}{*}{ SERRAVALLIAN } & Globigerinoides ruber & Globorotalia siakensis & Globorotalia siakensis & N13 & 2600 \\
\hline & Globorotalia foshi robusta & Globorotalia fohsi & Globorotalia fohsi & N12 & 2681 \\
\hline & Globorotalia foshi lobata & Globorotalia praefohsi & Globorotalia praefohsi & N11 & 2720 \\
\hline \multirow{3}{*}{ LANGHIAN } & Globorotalia fohsi fohsi & Globorotalia peripheroacuta & Globorotalia peripheroacuta & N10 & 2785 \\
\hline & $\begin{array}{l}\text { Globorotalia fohsi } \\
\text { peripheroronda }\end{array}$ & $\begin{array}{c}\text { Orbulina surturalis - } \\
\text { Globorotalia peripheroronda }\end{array}$ & Orbulina suturalis & N9 & 2860 \\
\hline & Praeorbulina glomerosa & Praeorbulina glomerosa curva & Praeorbulina sicana & N8 & 2926 \\
\hline \multirow[b]{2}{*}{ BURDIGALIAN } & Globigerinoides altiaperturus & Praeorbulina glomerosa sicana & Catapsydrax dissimilis & N7 & 3195 \\
\hline & Catapsydrax stainforthi & $\begin{array}{l}\text { Globigerinatella insueta/ } \\
\text { Globigerinita dissimilis }\end{array}$ & Globigerinatella insueta & N6 & 3290 \\
\hline \multirow{2}{*}{ AQUITANIAN } & Catapsydrax stainforthi & $\begin{array}{l}\text { Globoquadrina dehiscens praedehiscens/ } \\
\text { Globoquadrina dehiscens dehiscens }\end{array}$ & Paragloborotalia kugleri & N5 & 3324 \\
\hline & Globorotalis kugleri & $\begin{array}{l}\text { Globigerinoides quadrilobatus } \\
\text { primordius/Globorotalia kugleri }\end{array}$ & Globorotalis kugleri & N4 & 3400 \\
\hline
\end{tabular}

Globorotalia tumida at $1670 \mathrm{~m}$ indicates the lower Pliocene. The first occurrence of Globorotalia margaritae (Figure 2(a)) and Globorotalia plesiotumida at the $1816 \mathrm{~m}$ level mark the limit between the upper Miocene and the lower Pliocene, then confirms an age corresponding to the Blow [10] zone N18. The taxon Globorotalia margaritae is considered to be a very important biostratigraphic boundary separating the Miocene from the Pliocene [27] [28]. The species Globorotalia margaritae therefore characterizes the base of the Lower Pliocene [10] and is correlated with the Globorotalia crassaformis zone of Mboro et al. [17]. Subsequent to descent, the presence of plantonic foraminifera Globorotaloides variabilis, Globorotalia padan and Globorotalia juanai is recorded.

\section{b) Upper Miocene \\ i) Messinian}

\section{- Globorotalia merotumida (N17) zone}

The first occurrence of Globorotalia merotumida (Figure 2(b)) is located at a depth of $2150 \mathrm{~m}$, thus marking the base of the Messinian. The upper limit is at a 
depth of $1816 \mathrm{~m}$, defined by the first occurrence of Globorotalia margaritae. This interval corresponds to zone N17 of Blow [10] and, of Mboro et al. [17]. This space which covers the Messinian is also characterized by the first occurrence of Globigerinoides obliquus, Neogloboquadrina humerosa, Martinottiella communis and by the presence of Globigerinoides conglobatus, Globorotalia praebuloides, Globigerina obesa, Globorotalia venezuelana, Globorotalia juanai Pullenia bulloides and Orbulina saturalis.

\section{ii) Tortonian}

\section{- Globorotalia acostaensis (N16) zone}

The base of this interval is delimited at the level of $2265 \mathrm{~m}$ by the first occurrence of Globorotalia acostaensis (Figure 2(c)) while its top is located at a depth of $2150 \mathrm{~m}$ by the occurrence of Globorotalia merotumida. In this biozone, also exist Globigerinoides trilobus, Orbulina universa, Cibicidoides pseudoungerianus, Globorotalia praebulloides, Neogloboquadrina acostaensis. The Globorotalia acostaensis biozone is correlated with the N16 biozone (Globorotalia acostaensis) of Bolli [17], Blow [10], Postuma [29] and Mboro et al. [17].

\section{- Globorotalia menardii (N15) zone}

The level of first occurrence of Globorotalia menardii (Figure 2(d)) is located at $2307 \mathrm{~m}$ depth, thus marking the base of this interval. The top is at $2265 \mathrm{~m}$ marked by a first occurrence of Globorotalia acostaensis. This area is characterized by the presence of Orbulina universa and Globigerinoides obliquus. This interval is correlated with the $\mathrm{N} 15$ (Globorotalia menardii) zone from Bolli [22], Postuma [29], Mboro et al. [17] and the Globorotalia continuosa (N15) zone from Blow [10].

\section{- Globigerina nepenthes (N14) Zone}

The base is delimited at $2556 \mathrm{~m}$ depth by the first occurrence of Globigerina nepenthes (Figure 2(e)) and Globorotalia mayeri and the top is marked by the first occurrence of Globorotalia acostaensis at $2265 \mathrm{~m}$ depth. This interval is also characterized by the occurrence of Globorotalia menardii, Globigerina angustiumbilicata, and the presence of Globorotalia margaritae, Martinottiella communis, Globigerinoides triloba, Globigerinoides obliquus, Globigerinoides trilobus and Globigerina praulleboides. This zone is correlated with the Globorotalia mayeri (N14) zone of Bolli [22] and Mboro et al. [17].

\section{c) Middle Miocene}

\section{i) Serravallien}

\section{- Globorotalia siakensis (N13) zone}

The base of this interval is marked by the first occurrence of Globorotalia siakensis (Figure 2(f)) at $2600 \mathrm{~m}$ depth. The top is characterized by the first occurrence of Globigerina nepenthes at $2556 \mathrm{~m}$ depth. This zone is characterized by the occurrence of Cassigerinella chipolensis, Globigerinoides quadrilobatus, Globigerinella obesa, Globorotalia menardii, Globigerinoides immaturus, Sphaerodinelopsis subdehiscens, Orbulina suturalis, Uvigerina rustica and Trochammina globigeriniformis. This zone is correlated with the Globorotalia siakensis 
(N13) zone by Blow [10] and the Globigerinoides ruber (N13) zone by Bolli and Saunders [12].

\section{- Globorotalia fohsi(N12) zone}

The base and top of this area are marked by the occurrence and disappearance of Globorotalia fohsi (Figure 2(g)) at $2681 \mathrm{~m}$ (base) and $2600 \mathrm{~m}$ (top) respectively. This area also has the presence of Globorotalia praemenardii, Orbulina suturalis, Globorotalia obesa, Usbekistania charoides, Globigerina praebulloides, Globigerinoides quadrilobatus and Globigerinoides trilobus. It is correlated with the Globorotalia fohsi (N12) zone of Blow [9].

\section{- Globorotalia praefohsi (N11) zone}

The level of first occurrence of Globorotalia praefohsi (Figure 2(h)) is at a depth of $2720 \mathrm{~m}$ thus marking the base of this zone. The summit is defined by the first occurrence of Globorotalia fohsi at $2681 \mathrm{~m}$ depth. This area is characterized by the presence of Globorotalia fohsi fohsi, Orbulina suturalis, Cassigerinella chipolensis, Globorotalia obesa, Globigerina praebulloides, Globigerinoides trilobus and Globigerina angustiumbilicata. It is correlated with the Globorotalia praefohsi (N11) zone of Blow \& Banner [30] [31].

\section{ii) Langhien}

- Globorotalia peripheroacuta (N10) zone

The base of the area is delimited by the level of first occurrence of Globorotalia peripheroacuta (Figure 2 (i)) at $2785 \mathrm{~m}$ depth and the summit is defined by the first occurrence of Globorotalia praefohsi at a depth of $2720 \mathrm{~m}$. This area is also marked by the first occurrence of Globigerinoides triloba and Globorotalia archeomenardii. It is correlated with the Globorotalia peripheroacuta (N10) zone of Blow [10].

\section{- Orbulina suturalis (N9) zone}

The top of this zone is defined by the level of the first occurrence of Praeorbulina glomerosa at a depth of $2785 \mathrm{~m}$, while the base is marked by the first occurrence of Orbulina suturalis (Figure $2(\mathrm{j})$ ) at a depth of $2860 \mathrm{~m}$. This area is characterized by the first appearance of Globorotalia peripheroronda and then by the presence of Globorotalia Obesa, Orbulina universa and Globigerinoides trilobus. The zone with Orbulina universa is equivalent to the zone Globorotalia peripheroronda (N9) of Blow [10].

- Praeorbulina sicana (N8) zone

The base of the area is defined by the level of first occurrence of Praeorbulina sicana (Figure $2(\mathrm{k})$ ) at $2926 \mathrm{~m}$ depth, and the summit is marked by the first occurrence of Globorotalia peripheroronda at $2860 \mathrm{~m}$ depth. This interval is also characterized by the presence of Praeorbulina curva and Globigerinatella insueta which correspond to zone N8 (Praeorbulina sicana) of Blow [10]. The Praeorbulina sicana area is also marked by the presence of Globorotalia birnageae, Globorotalia bella, Praeorbulina glomerosa glomerosa, Globorotalia archeomenardii, Paragloborotalia semivera and Globigerinoides bisphericus. 

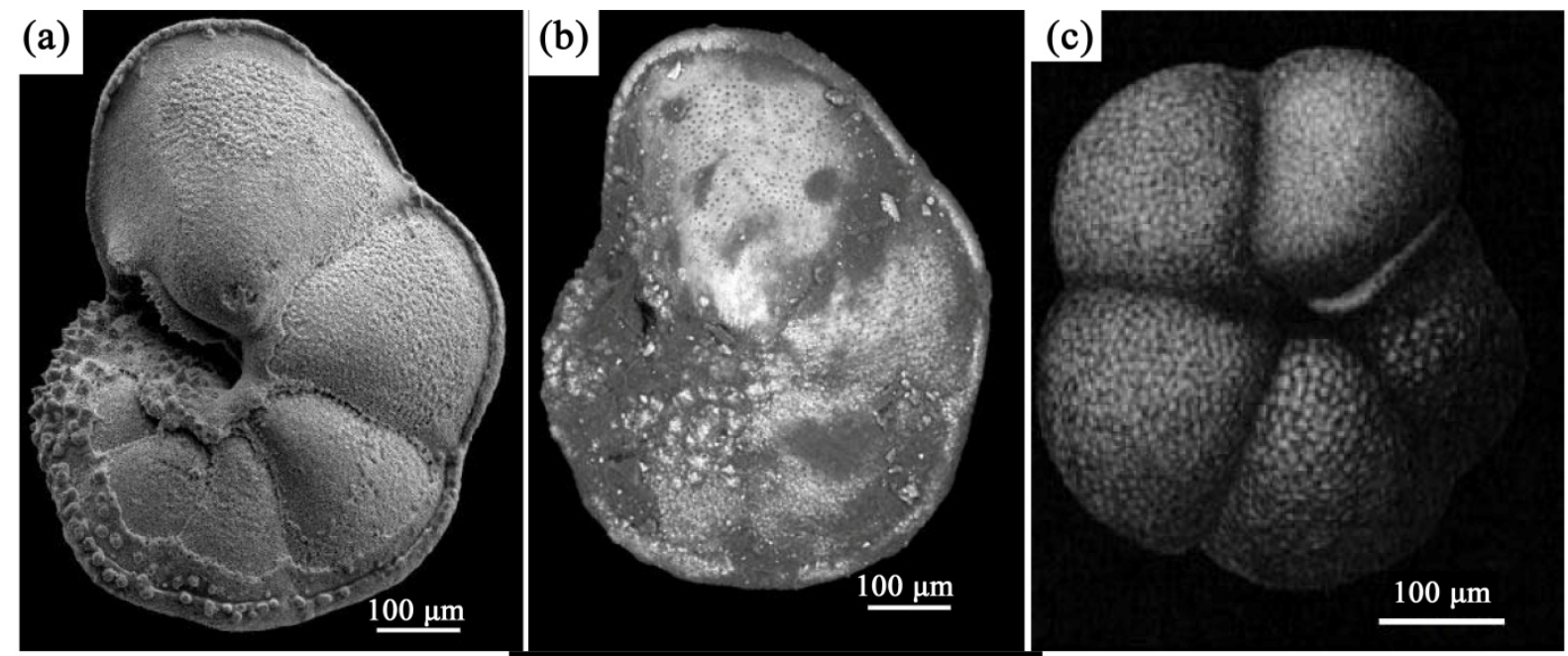

(e)
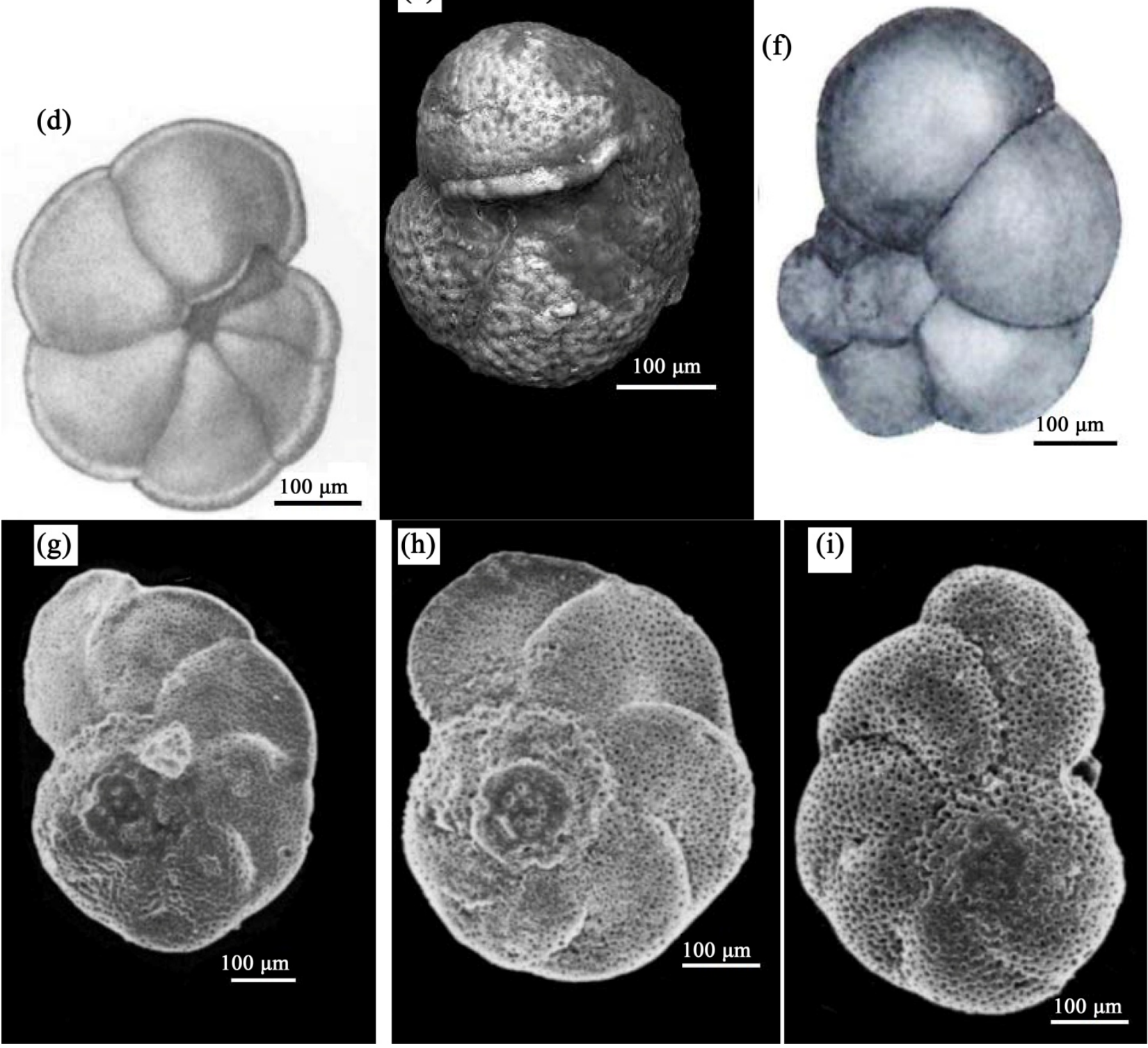

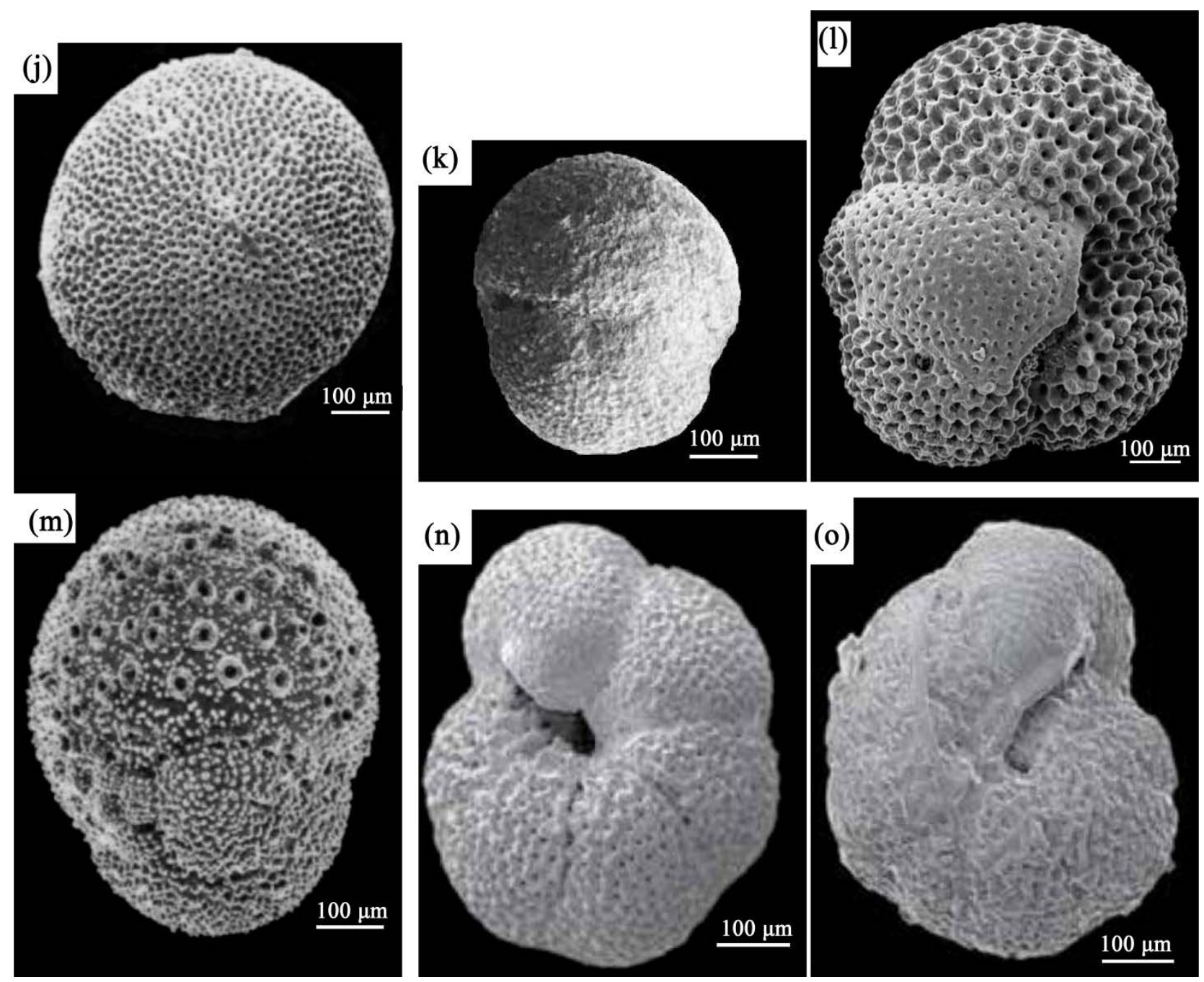

Figure 2. (a) Globorotalia plesiotumida; (b) Globorotalia merotumida; (c) Globorotalia acostaensis; (d) Globorotalia menardii; (e) Globigerina nepenthes; (f) Globorotalia siakensis; (g) Globorotalia fohsi; (h) Globorotalia praefohsi; (i) Globorotalia peripheroacuta. (j) Orbulina suturalis; (k) Praeorbulina sicana; (l) Catapsydrax dissimilis; (m) Globigerinatella insueta; (n) Paragloborotalia kugleri; (o) Globorotalia kugleri. All of these images are taken at size $100 \mu \mathrm{m}$.

\section{d) Lower Miocene \\ i) Burdigalien}

\section{- Catapsydrax dissimilis (N7) zone}

The level of first occurrence of Catapsydrax dissimilis (Figure 2(1)) is at a depth of $3195 \mathrm{~m}$ thus marking the base of this area. The summit is defined by the first occurrence of Globorotalia peripheroronda at a depth of $2926 \mathrm{~m}$. This area is characterized by the presence of Globigerinoides altiaperturus, Globigerinoides bisphericus, Globigerinoides trilobus, Globorotalia birnagae, Catapsydrax stainforthi. This interval is correlated with the N7 zone at Catapsydrax dissimilis of Blow [10].

\section{- Globigerinatella insueta (N6) zone}

The base of the area is delimited by the level of first occurrence of Globigerinatella insueta (Figure $2(\mathrm{~m})$ ) at $3290 \mathrm{~m}$ depth and the summit is defined by the 
first occurrence of Catapsydrax dissimilis at a depth of $3195 \mathrm{~m}$. This area is characterized by the presence of Globorotalia birnageae, Globigerinoides bisphericus, Globorotalia praescitula, Globigerinoides sacculifer, Globigerinoides altiaperturus and Globigerinoides quadrilobatus. It is correlated with the N6 zone caused by Globigerinatella insueta by Blow [10].

\section{ii) Aquitanian}

\section{- Paragloborotalia kugleri (N5) zone}

The level of first occurrence of Paragloborotalia kugleri (Figure 2(n)) is at a depth of $3324 \mathrm{~m}$ marking the base of this zone. The summit is defined by the first occurrence of Globigerinatella insueta at $3290 \mathrm{~m}$ depth. This area is characterized by the presence of Globorotalia obesa, Globorotalia bella, Globigerinoides sacculifer, Globigerina wooki, Globoquadrina venezuelana, Globigerina praebulloides and Cassigerinella chipolensis. It is correlated with the N5 zone at Globorotalia kugleri by Blow [10].

\section{- Globorotalia kugleri (N4) zone}

This zone is defined at its base by the first occurrence of Globigerinoides primordius at the $3400 \mathrm{~m}$ level and by the last appearance of Globorotalia kugleri (Figure 2(o)) marking the summit at $3324 \mathrm{~m}$. This zone is also characterized by the presence of the planktonic foraminifera Fohsella kugleri, Globigerina ciperoensis, Globorotalia siakensis, Globorotalia obesa, Globigerina venezuelana, Globoquadrina praedehiscens, Globoquadrina altispira globosa and Globoquadrina dehiscens. This interval is correlated with the N4 zone at Fohsella kugleri by Blow [10].

\section{2) DEPOSIT PALEOENVIRONMENTS}

The environment containing planktonic foraminifers is very complex and its description includes many parameters such as temperature, salinity, mixing depth of the water column, turbidity, nutrient composition, type and abundance of prey. (Hemleben et al. [32], 198; Kemle-von Mücke and Hemleben, [33]) indicating a strong link between planktonic foraminifera and hydrological parameters. It is recognized that the size of planktonic foraminifers varies with temperature and primary production [34]-[39]. Temperature is therefore considered to be one of the major factors influencing the size and growth of planktonic foraminifera [35] [39] [40] [41]. However, the definition of Miocene paleoenvironments in relation to the various biozones raised is based on three criteria:

- The relationship in the abundance and diversity of species;

- The planktonic/benthic ratio $(\mathrm{P} / \mathrm{B})$;

- limestone/Arenaceous tests report.

Deposition environments vary from bathyal to abyssal glacis with the direct influence of the sea. A paleo-environmental model of deposition related to bathymetry is proposed (Figure 3 ).

\section{a) Upper Miocene (1670 m - $2556 \mathrm{~m})$ \\ Messinian-Tortonian}

The interval is characterized by a good content in abundance and diversity of 


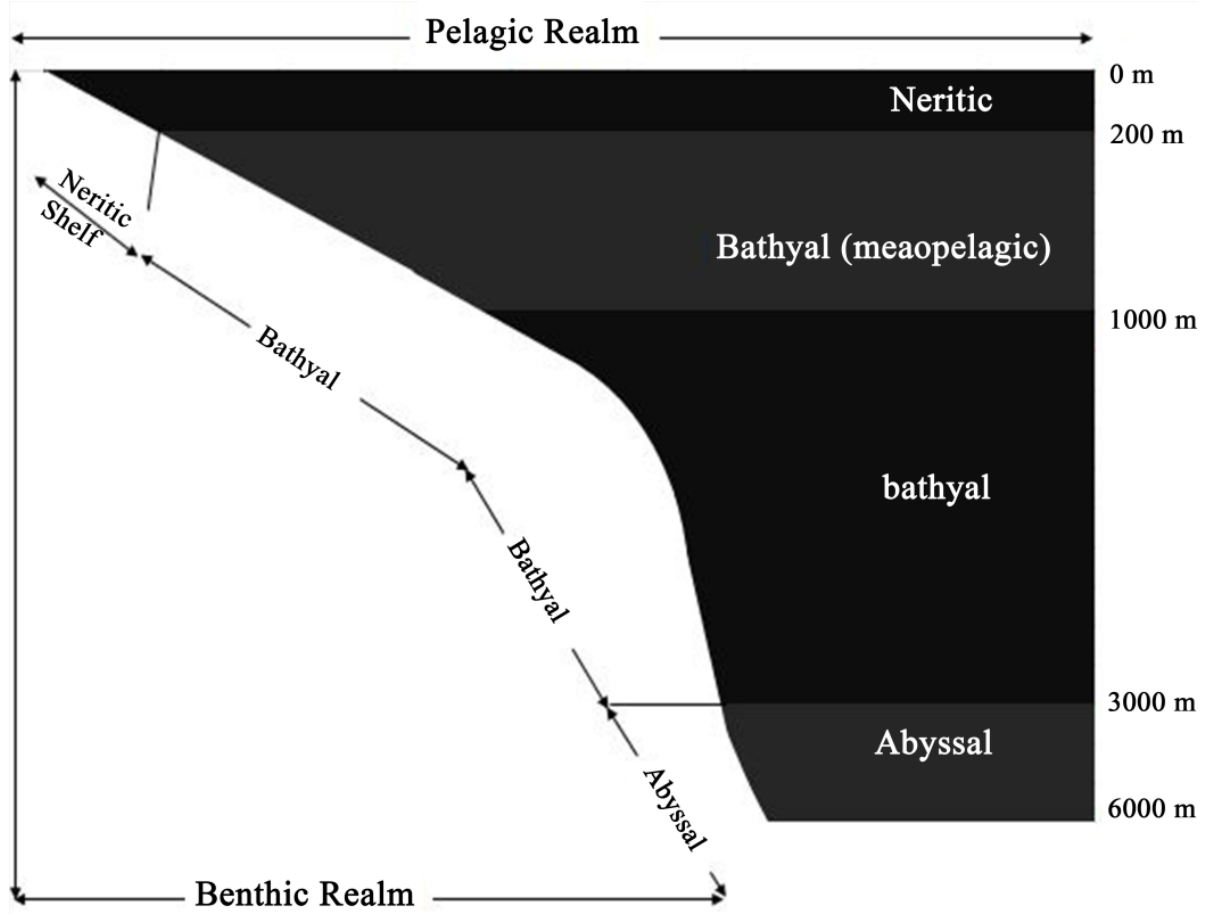

Figure 3. Paleobathymetric and paleoenvironmental zonation.

calcareous benthic and planktonic foraminifera between $1670 \mathrm{~m}$ and $2556 \mathrm{~m}$. The recorded $\mathrm{P} / \mathrm{B}$ values are high and here testify to a considerable increase in sea level caused by a transgression [17]. The abundance of planktonic foraminifera indicates an open marine environment. From $1670 \mathrm{~m}$ to $1890 \mathrm{~m}$, the presence of the benthic foraminifera Martinottiella communis, Pullenia bulloides and Sphaeroidina bulloides characterize an upper bathyal environment [42]. Between $1890 \mathrm{~m}$ and $2330 \mathrm{~m}$ the microfauna is entirely made up of Martinottiella communis and radiolarians, which reveals a relatively deeper bathyal environment. Below $2330 \mathrm{~m}$, the microfauna is dominated by agglutinating non-calcareous foraminifera up to $2470 \mathrm{~m}$, indicating a deep marine deposition environment. Between $2470 \mathrm{~m}$ and $2521 \mathrm{~m}$, a rich microfauna comprising abundant benthic and planktonic species suggests an outer shelf to upper bathyal environment [42]. Samples collected below $2521 \mathrm{~m}$ are rich in assemblages of agglutinating foraminifera with abundant radiolaria, indicating a deeper bathyal environment. The presence of Globigerinoides bulloides specimens often considered as a marker of upwelling environment at low attitudes, Bé and Hutson [43] found in deep water, in symbiosis with the genus Neogloboquadrina pachyderma indicate a relatively nutrient-rich lower bathyal environment [44]-[51]. The Foraminifera Orbulina universa is considered a warm-water species and lives in symbiosis with dinoflagellates [32] [52]. The Globigerinoides trilobus species preferentially lives between 21 and $29^{\circ} \mathrm{C}$ [41] [44] [53] [54].

The association of Globigerinoides trilobus and Orbulina universa in constant symbiosis with dinoflagellates characterizes a photic environment [32] [55]. Globorotalia species are commonly considered to be deep species [43] [32]. How- 
ever, the mixture of the foraminifera Globigerinoides bulloides, Obulina universa, Globigerinoide trilobus, Neogloboquadrina pachyderma and the genus Globorotalia can be considered as the effect of a post-mortem transport of species living in the shallow environment to the deep environment or simply by the bioturbation effects [17].

b) Middle Miocene (2556 m - $2926 \mathrm{~m}$ )

\section{Serravalien-Langhian}

The Middle Miocene is moderately fossiliferous. The interval is characterized by low abundance and diversity of species. The low values of $\mathrm{P} / \mathrm{B}$ and $\mathrm{C} / \mathrm{A}$ reflect a shallow marine environment. The presence of abundant glauconite contained in some samples confirms a shallower deposition environment, therefore from the outer platform to the upper bathyal. The presence of Cibicidoides at $2720 \mathrm{~m}$, species characteristic of a muddy environment of shallow water with low tolerance of salinity and oxygen deficiency [56] [57]; Hanzawaia epipelic from Murray [42] and Pullenia bulloides, endopelic from Murray [58], characteristic of marine conditions of good oxygenation, external platform to bathyal [59]; these benthic foraminifera characterize well a shallow deposition environment. Samples collected between $2800 \mathrm{~m}$ and $2926 \mathrm{~m}$ are weakly fossiliferous composed of a high number of benthic foraminifers with a reduced number of planktonic foraminifers thus marking a shallow bathyal deposition environment.

c) Lower Miocene (2926 m - $3400 \mathrm{~m})$

\section{Burdigalien-Aquitanien}

The Lower Miocene samples are generally weakly fossiliferous, reflecting the dysaerobic nature of the deposit in relatively deeper water. The Burdigalian section, from $2926 \mathrm{~m}$ to $3195 \mathrm{~m}$, is made up of mixed assemblages of planktonic, benthic, calcareous and agglutinating foraminifers which characterize an upper bathyal environment with an oxygenated bottom. Between $3195 \mathrm{~m}$ and $3400 \mathrm{~m}$, although weakly fossiliferous, the Lower Miocene is composed of a high number of agglutinating foraminifers, with very low recovery of planktonic foraminifera. The majority of the samples collected are weakly calcareous and indicate a deeper to abyssal bathyal environment.

\section{Conclusion}

The North deep sea block was the subject of a study using sediments collected from four wells. This study made it possible to define the lithological characteristics, to carry out a micropaleontological inventory based on planktonic foraminifera, to establish the age of the sediments, biozones and deposit environments of the Miocene. This study shows a lithological variation in the sediments dominated by dark clays, but marked by an alternation of dark clays, more or less clayey siltstones, fine to coarse sands and limestone. On the basis of the foraminifera collected, the biostratigraphic analysis revealed several bioevents of planktonic foraminifera making it possible to identify fifteen (15) biozones (Globorotalia plesiotumida, Globorotalia merotumida, Globorotalia acostaensis, Glo- 
borotalia menardii, Globigerina nepenthes, Globorotalia siakensis, Globorotalia fohsi, Globorotalia praefohsi, Globorotalia peripheroacuta, Globorotalia peripheroronda, Praeorbulina sicana, Catapsydrax dissimilis, Globigerinatella insueta, Paragloborotalia kugleri and Globorotalia kugleri) corresponding to age between Aquitanian and Messinian. The micropaleontological harvest is progressively excellent, moderate and weak depending on the sedimentation medium. The biofacies analysis of foraminifera has made it possible to define the palaeoenvironmental characteristics which vary from open marine environments, bathyal to abyssal. The biostratigraphic and biozonation results obtained make it possible to resolve the questions of sequential stratigraphy.

\section{Acknowledgments}

We are very grateful to Murphy and the National Petroleum Society of the Congo (snpc) for leading this research. We thank to the General Director of the Geological and Mining Research Center (CRGM) for the constructive comments and his contribution to the improvement of this article.

\section{Conflicts of Interest}

The authors declare no conflicts of interest regarding the publication of this paper.

\section{References}

[1] Desthieu, et al. (1993) Notice explicative de la carte géologique du Congo au 1/1000000. Ministère des Mines et de l'Energie, Brazzaville, 25

[2] Kouyoumontzakis, G. (1979) La microfaune benthique du plateau continental congolais. Inventaire, répartition, stratigraphie du Quaternaire supérieur. Rapports avec le milieu sédimentaire. Thèse de Doctorat de spécialité, Aix-Marseille II, Provence-Alpes-Côte d'Azur.

[3] Kouyoumontzakis, G. (1983) Les Foraminifères vivant dans le substratum du biotope à Geryon quinquedens (Crustacé, Décapode) au large de la République Populaire du Congo. Annales de l'Université de Brazzaville, 18, 19(C).

[4] M’boro, R. (1980) Le bassin de Pointe-Noire (Congo) du Sénonien au Néogène. Vol. 2, Thèse de doctorat de l' Université de Provence, Marseille, 336, 35 pl.

[5] N'gatse, L.R. (1989) Les ostracodes du post-salifère congolais du Crétacé inférieur au Miocène: systématique, stratigraphie, biogéographie. Thèse de Doctorat de l'Univ. Pierre et Marie Curie (Paris VI), Paris.

[6] Massala, A. (1993) Le Crétacé supérieur et le Tertiaire du Bassin côtier congolais. Biochronologie et stratigraphie séquentielle. Thèse Université de Bourgogne, Dijon, $323 \mathrm{p}$.

[7] Giresse, P., Jansen, F.-H., Kouyoumontzakis, G. and Moguedet, G. (1981) Les fonds de la plateforme congolaise, le delta sous-marin du fleuve Congo. Bilan de huit ans de recherches sédimentologiques, paléontologiques, géochimiques et géophysiques. In: Fontana, A., Ed., Milieu marin et ressources halieutiques de la République Populaire du Congo, Travaux et Doc. No. 138, Office de la recherche scientifique et technique outre-mer, Paris, 13-45. 
[8] Giresse, P. and Baloka, R. (1997) Les phosphates méso-cénozoïques du bassin du Congo et leurs environnements. Bulletin de la Société Géologique de France, 168, 585-600.

[9] Mbani, J. (2008) Micropaléontologie et géochimie organique du bassin côtier congolais au Crétacé supérieur: Paléoécologie des foraminifères, espèces et associations indicatrices des paléoenvironnements des roches mères pétrolières. Thèse de 3ème cycle, Université Paris VI, Paris.

[10] Blow, W.H. (1969) Late Middle Eocene to Recent planktonic foraminiferal Biostratigraphy. Proceedings of the 1 st International Conference on Planktonic Microfossils, Vol. 1, Geneva, 1967, 199-422.

[11] Blow, W.H. (1979) The Cainozoic Globigerinidae. A Study of the Morphology, Taxonomy, Evolutionary Relationship and the Stratigraphical Distribution of Some Globigerinidae (Mainly Globigerinacea). E.J. Brill, Leiden, Netherlands, 3 Vols, 1413 pp.

[12] Bolli, H.M. and Saunders, J.B. (1985) Oligocene to Holocene Low Latitude Planktonic Foraminifera. Plankton Stratigraphy. In: Bolli, H.M., Saunders, J.B. and Perch-Nielsen, K., Eds, Plankton Stratigraphy, Cambridge University Press, Cambridge, 155-257.

[13] Loeblich Jr., A.R. and Tappan, H. (1987) Genres foraminiféraux et leurs classification. Vol. 2, Vune société Nostrand Reinhold, New York, 970 pages.

[14] Hardenbol, J., Thierry, J., Farley, M.B., Jacquin, T., de Graciansky, P.C. and Vail, P.R. (1998) Mesozoic and Cenozoic Sequence Chronostratigraphic Framework of European Basins. In: de Graciansky, P.C., Hardenbol, J., Jacquin, T. and Vail, P.R., Eds., Mesozoic and Cenozoic Sequence Stratigraphy of European Basins, Special Publication Vol. 60, Society for Sedimentary Geology (SEPM), Tulsa, 3-14, appendix 763-782+8 charts.

[15] Berggren, W.A., Kent, D.V., Swisher III, C.C. and Aubry, M.-P. (1995) A Revised Cenozoic Geochronology and Chronostratigraphy. Special Publications of SEPM, Society for Sedimentary Geology (SEPM), Tulsa.

[16] Olsson, R.K., Hemleben, C., Berggren, O.A. and Huber, B.T. (1999) Atlas de foraminifères planctoniques du Paléocène: Contributions du Smithsonian a Paleobiology. Vol. 85, Smithsonian Institution Press, Washington DC, 1-252. https://doi.org/10.5479/si.00810266.85.1

[17] Mboro, R., Anglada, R. and Brun, L. (1981) Le Bassin de Pointe-Noire (Congo), du Sénonien Supérieur au Néogène (stratigraphie-paléogéographie). Cahiers de micropaléontologie, No. 4, 73-102.

[18] Berggren, W.A. (1971) Tertiary Boundaries and Correlations. In: Funnell, B.M. and Riedel, W.R., Eds., The Micropaleontology of Oceans, Cambridge University Press, London, 693-809.

[19] Berggren, W.A. (1972) Cenozoic Biostratigraphy and Paleo-Biogeography of the North Atlantic. Initial Reports of the Deep-Sea Drilling Project, 12, 965-1001. https://doi.org/10.2973/dsdp.proc.12.114.1972

[20] Berggren, W.A. (1973) The Pliocene Time Scale: Calibration of Planktonic Foraminiferal and Calcareous Nannoplankton Zones. Nature, 243, 391-397.

https://doi.org/10.1038/243391a0

[21] Berggren, W.A. and van Couvering, J.A. (1974) The Late Neogene: Biostratigraphy, Geochronology and Paleoclimatology of the Last 15 Million Years in Marine and Continental Sequences. Palaeogeogr, Palaeoclimatol, Palaeoecol, 16, 1-216. https://doi.org/10.1016/0031-0182(74)90032-7 
[22] Bolli, H.M. (1966) The Planktonic Foraminifera in Well Bodjonegoro-1 of Java. Eclogae Geologicae Helvetiae, 59, 449-465.

[23] Bolli, H.M. and Bermudez, P.J. (1957) Planktonic Foraminifera from the Oligocene-Miocene Cipero and Lengua Formations of Trinidad, B.W.I. U.S. National Museum Bulletin, 215, 97-123.

[24] Bolli, H.M. and Bermudez, P.J. (1965) Zonation Based on Planktonic Foraminifera of Middle Miocene to Pliocene Warm-Water Sediments. Boletin Informativo Associacion Venezolana de Geologia, Mineria y Petroleo, 8, 119-149.

[25] Premoli-Silva, I. and Bolli, H.M. (1973) Late Cretaceous to Eocene Planktonic Foraminifera and Stratigraphy of Leg 15 Sites in the Caribbean Sea. In: Edgari, N.T., Saunders, J.B., et al., Eds., Initial Reports of the Deep Sea Drilling Project, Vol. 15, United States Government Printing Office, Washington DC, 499-547.

[26] Lamb, J.L. and Beard, J.H. (1972) Foraminifères planctoniques du Néogène tardif dans les stratotypes des Caraïbes, du golfe du Mexique et d'Italie. Contributions paléontologiques de 1 Université du Kansas, 57, 67 p.

[27] Stainforth, R.M., Lamb, J.L., Luterbacher, H., Beard, J.H. and Jeffords, R.M. (1975) Cenozoic Planktonic Foraminiferal Zonation and Characteristics of Index Forms. University of Kansas Paleontological Contributions, Lawrence, Article No. 62, 425 p.

[28] Cifelli, R. and Glaçon, R. (1979) New Late Miocene and Pliocene Occurrences of Globorotalia Species from the North Atlantic; and a Paleogeographic Review. Journal of Foraminiferal Research, 9, 210-227. https://doi.org/10.2113/gsjfr.9.3.210

[29] Postuma, J.A. (1971) Manual of Planktonic Foraminifera. Elsevier, New York, 420 p.

[30] Blow, W.H. and Banner, F.T. (1966) The Morphology, Taxonomy and Biostratigraphy of Globorotalia Barisanensis LeRoy, Globorotalia Fohsi Cushman and Ellisor, and Related Taxa. Micropaleontology, 12, 286-302, pls.1-2. https://doi.org/10.2307/1484548

[31] Banner, F.T. and Blow, W.H. (1965) Progress in the Planktonic Foraminiferal Biostratigraphy of Neogene. Nature, 208, 1164-1166. https://doi.org/10.1038/2081164a0

[32] Hemleben, C., Spindler, M. and Roger Anderson, O. (1989) Modern Planktonic Foraminifera. Springer, New York, 363 p. https://doi.org/10.1007/978-1-4612-3544-6

[33] Kemle-Von Mücke S. and Hemleben C. (1999) Foraminifera. In: Boltovskoy, D., Ed., South Atlantic Zooplankton, Backhuys Publishers, Leiden, 43-73.

[34] Bé, A.W.H., Harrison, S.M. and Lott, L. (1973) Orbulina universa d'Orbigny in the Indian Ocean. Micropaleontology, 19, 150-192. https://doi.org/10.2307/1485162

[35] Hecht, A.D. (1976) An Ecologic Model for Test Size Variation in Recent Planktonic Foraminifera: Applications to the Fossil Record. Journal of Foraminiferal Research, 6, 295-311. https://doi.org/10.2113/gsifr.6.4.295

[36] Fairbanks, R.G. and Wiebe, P.H. (1980) Foraminifera and Chlorophyll Maximum: Vertical Distribution, Seasonal Succession, and Paleoceanographic Significance. Science, 209, 1524-1526. https://doi.org/10.1126/science.209.4464.1524

[37] Ortiz, J.D., Mix, A.C. and Collier, R.W. (1995) Environmental Control of Living Symbiotic and Asymbiontic Foraminifera of the Californian Current. Paleoceanography, 10, 987-1009. https://doi.org/10.1029/95PA02088

[38] Naidu, P.D. and Malmgren, B.A. (1996) A High-Resolution Record of Late Quaternary Upwelling along the Oman Margin, Arabian Sea Based on Planktonic Foraminifera. Paleoceanography, 11, 129-140. https://doi.org/10.1029/95PA03198

[39] Schmidt, D.N., Renaud, S., Bollmann, J., Schiebel, R. and Thierstein, H.R. (2004) 
Size Distribution of Holocene Planktic Foraminifer Assemblages: Biogeography, Ecology and Adaptation. Marine Micropaleontology, 50, 319-338. https://doi.org/10.1016/S0377-8398(03)00098-7

[40] Bijma, J., Erez, W.W. and Hemleben, C. (1990) Lunar and Semi-Lunar Reproductive Cycles in Some Spinose Planktonic Foraminifers. Journal of Foraminiferal Research, 20, 117-127. https://doi.org/10.2113/gsjfr.20.2.117

[41] Bijma, J., Faber, W.W. and Hemleben, C. (1990) Temperature and Salinity Limits for Growth and Survival of Some Planktonic Foraminifers in Laboratory Cultures. Journal of Foraminiferal Research, 20, 95-116. https://doi.org/10.2113/gsjfr.20.2.95

[42] Murray, J.W. (1991) Ecology and Palaeoecology of Benthic Foraminifera. Longman Scientific \& Technical, Haarlow, 397 p.

[43] Bé, A.W.H. and Hutson, W.H. (1977) Ecology of Planktonic Foraminifera and Biogeographic Patterns of Life and Fossil Assemblages in the Indian Ocean. Micropaleontology, 23, 369-414. https://doi.org/10.2307/1485406

[44] Tolderlund, D.S. and Bé, A.W.H. (1971) Seasonal Distribution of Planktonic Foraminifera in the Western North Atlantic. Micropaleontology, 17, 297-329. https://doi.org/10.2307/1485143

[45] Thiede, J. (1975) Distribution of Foraminifera in Surface Waters of a Coastal Upwelling Rea. Nature, 253, 712-714. https://doi.org/10.1038/253712a0

[46] Sautter, L.R. and Thunell, R.C. (1991) Planktonic Foraminiferal Response to Upwelling and Seasonal Hydrographic Conditions: Sediment Trap Results from San Pedro Basin, Southern California Bight. Journal of Foraminiferal Research, 21, 347-363. https://doi.org/10.2113/gsjfr.21.4.347

[47] Ufkes, E. and Zachariasse, W.J. (1993) Origin of Coiling Differences in Living Neogloboquadrinids in the Walvis Bay Region, off Namibia, Southwest Africa. Micropaleontology, 39, 283-287. https://doi.org/10.2307/1485901

[48] Mücke, S.K.-V. and Oberhänsli, H. (1999). The Distribution of Living Planktic Foraminifera in Relation to Southeast Atlantic Oceanography. In: Fischer, G. and Wefer, G., Eds., Use of Proxies in Paleoceanography: Examples from the South Atlantic, Springer-Verlag, Berlin, Heildelberg, 91-115.

https://doi.org/10.1007/978-3-642-58646-0_3

[49] Peeters, F. (2000) The Distribution and Stable Isotope Composition of Living Planktic Foraminifera in Relation to Seasonal Changes in the Arabian Sea, Free University, Amsterdam.

[50] Ivanova, E.M., Conan, S.M.H., Peeters, F.J.C. and Troelstra, S.R. (1999) Living Neogloboquadrina pachyderma Sin and Its Distribution in the Sediments from Oman and Somalia Upwelling Areas. Marine Micropaleontology, 36, 91-107. https://doi.org/10.1016/S0377-8398(98)00027-9

[51] Salgueiro, E., Voelker, A., Abrantes, F., Meggers, H., Pflaumann, U., Loncaric, N., Gonzales-Alvarez, R., Oliveira, P., Bartels-Jonsdottir, H.B., Moreno, J. and Wefer, G. (2008) Planktonic Foraminifera from Modern Sediments Reflect Upwelling Patterns off Iberia: Insights from a Regional Transfer Function. Marine Micropaleontology, 66, 135-164. https://doi.org/10.1016/j.marmicro.2007.09.003

[52] Spero, H.J. (1987) Symbiosis in the Planktonic Foraminifer, Orbulina universa, and the Isolation of Its Symbiotic Dinoflagellate, Gymnodinium béii sp. Nov. Journal of Phycology, 23, 307-317. https://doi.org/10.1111/j.1529-8817.1987.tb04139.x

[53] Bé, A.W., Hemleben, C., Anderson, O.R., Spindler, M., Hacunda, J. and Tuntivate-Choy, S. (1977) Laboratory and Field Observations of Living Planktonic Fora- 
minifera. Micropaleontology, 23, 155-179. https://doi.org/10.2307/1485330

[54] Lombard, F., Labeyrie, L., Michel, E., Spero, H.J. and Lea, D.W. (2009) Modelling the Temperature Dependent Growth Rates of Planktic Foraminifera. Marine Micropaleontology, 70, 1-7. https://doi.org/10.1016/j.marmicro.2008.09.004

[55] Hemleben, C. and Spindler, M. (1983) Recent Advances in Research on Living Planktonic Foraminifera. Utrecht Micropaleontological Bulletin, 30, 141-170.

[56] Hageman, J. (1979) Assemblages de foraminifères benthiques de la baie ouverte du Plio-Pléistocène aux sediments lagunaire de l'ouest du Péloponnèse (Grèce). Utrecht Micropaleontol. Taureau, 20, 1-180.

[57] Van Der Zwaan, G.J. (1982) Paleoecology of Late Miocene Foraminifera. Utrecht Micropaleontological Bulletin, 25, 202 p.

[58] Murray, J.W. (2006) Ecology and Application of Benthic Foraminifera. Cambridge University Press, New York, 426 p.

[59] Steffahn, J. and Michalzick, D. (2000) Nature and Timing of Marine Post-Crisis Foraminiferal Repopulation (Messinian Event; Late Tertiary) in the Lorca Basin, SE Spain. Revista Espanola de Micropaleontologia, 32, 371-383. 